\title{
THEORETICAL AND PRACTICAL ASPECTS OF USE OF ELECTROSHOCK WEAPON
}

\author{
Sergejs Talapins ${ }^{1}$, Eduards Agafonovs ${ }^{2}$ \\ ${ }^{1}$ Prof.bc., Bc.ing., Assistant of Border Guard and Immigration Service Subjects \\ Department of the State Border Guard College, \\ e-mail: sergejs.talapins@rs.gov.lv, Rēzekne, Latvia \\ ${ }^{2} \mathrm{Mg}$.jur., Assistant of Docent of Border Guard and Immigration Service Subjects \\ Department of the State Border Guard College, \\ e-mail: eduards.agafonovs@rs.gov.lv, Rēzekne, Latvia
}

\begin{abstract}
Currently, the use of firearms and special devices by law enforcement agencies in civilised democracies is strictly determined in accordance with the current legislation on the use of firearms and special devices. Their illegitimate or unauthorised application causes censure and sparks public outcry. Nevertheless, sometimes situations arise in which it is difficult and problematic for a law enforcement officer to make the right decision on the use of firearms, physical force, special devices and military working dogs. At the moment, the officers of the Latvian Border Guard are often simply unable to resist the illegal actions of offenders, since the current legislation is not always capable of justifying the lawful actions of the border guard. Also, sometimes the specific character of duty performance (a large crowd of people, the proximity of the state border) makes it impossible to use firearms. At the same time, the lack of regular training on the practical use of special devices (stack, handcuffs and others) significantly reduces the chances of their successful use by the Latvian Border Guard officers. Bearing and using electroshock weapons, and specifically stun guns of the TASER type, will significantly increase the level of security of the Latvian Border Guard staff, and will also allow the use of stun guns to ensure public order without risk to others and with minimal risk to the offender. The stun guns will allow you to blur the lines between physical abilities and the degree of physical fitness of the border guard and the offender, as a result of which a fragile girl - border guard can easily neutralise a raging athlete who is trying to disrupt public order and border control order with minimal harm.
\end{abstract}

Keywords: electroshock weapon, Latvian Border Guard, special devices, Taser, X26.

\section{Introduction}

The application of firearms, physical force, special devices and military working dogs in the duty performance, in our time, is often the cornerstone between the law and an official using weapons and special devices. A border guard, while performing service duties, is obliged to protect the law, which provides, if necessary, for the use of firearms, physical force, special devices and military working dogs, but at the same time the border guard must strictly comply with the requirements of the law.

The study of this issue is more than relevant today, when society requires an increasingly humane attitude towards itself in various aspects of life. In this regard, it is becoming increasingly difficult for law enforcement officials to protect the law and society from offenders, since 
the use of firearms and other more drastic remedies is censured by society and causes a public outcry. Therefore, law enforcement officers often face a problem how to protect society from the offender and inflict minimal harm on the offender. The authors of the work conducted a research of the use of stun guns over the past three years by law enforcement officers in Europe, the United States and the Russian Federation. Research methods consist in the study and analysis of materials available in the media, documentaries, as well as the use of personal experience of using special devices.

The main objective of this work is to prove the existence of a more humane means of ensuring public order than firearms and more effective than other special devices. Hypothesis of the work: all border guards performing service duties related to the immediate protection of the state border, as well as ensuring control of the immigration regime, must have stun guns during the performance of their service duties.

\section{Peculiarities of use of stun guns by Latvian Border Guard officers}

According to the Border Guard Law of the Republic of Latvia, a border guard, while performing service duties, is entitled to use physical force, special devices and military working dogs in the following cases:

1. To repel an attack on border guards and other persons;

2. To arrest persons who, with malicious intent, do not submit to or resist border guards;

3. To restrain the detained and arrested persons if they do not submit to or resist border guards when they are accommodated, removed or transferred under the supervision of security guards, or there is a reasonable suspicion that they may abscond or harm people nearby or themselves;

4. To repel assault to buildings, separate premises and means of transport that are guarded by border guards, as well as to liberate these objects if they have been taken over by armed persons;

5. To interrupt mass disorder and violations of public order if they have been committed in a group of persons (Border Guard Law, 1997).

Also, the Border Guard Law of the Republic of Latvia establishes the rules for the use of firearms. According to them, a border guard is entitled to use a firearm in order:

1. To repel an armed attack in the territory of Latvia or to terminate armed resistance by attackers;

2. To arrest a person violating the State border, if there is no other way of arresting the person;

3. To repel an attack and to terminate resistance, also an attack and resistance by unarmed persons, if actual threats are created to the life 
of the border guard or other persons and if it is not possible to prevent such or if it is necessary to prevent an attempt to obtain a firearm through violence;

4. To stop a means of transport, causing damage to it, if its driver through his or her actions is causing actual threats to the life or health of a border guard or other persons and does not submit to a request by a border guard to stop the means of transport and if there is no other way to arrest the driver (Border Guard Law, 1997).

Considering the Section on the use of firearms, we would like to analyse the second paragraph on the use of firearms: "... To arrest a person violating the State border, if there is no other way of arresting the person." Based on a hard-boiled appraisal of the situation, we can confidently state that the other way always exists. And in the case of the use of firearms in such a situation, the border guard will be held accountable before the law, because there was "the other way."

Circumstances which exclude criminal liability, even if acts committed in such circumstances correspond to the constituent elements of a criminal offence provided for in the Criminal Law, are necessary self-defence, detention causing personal harm, extreme necessity, justifiable professional risk, and execution of a criminal command or criminal order (Criminal Law, 1998).

Consider a situation where a state border violator runs away from a border guard, ignoring commands and not reacting to warning shots. The border guard tries to arrest the criminal, but he fails to catch up with him due to the better physical fitness of the latter. Let's also imagine that in order to catch up with the violator, the border guard lacks five to seven meters. What remains to be done in such a situation? The first option is to let the violator go, thus not fulfilling service duties. In accordance with Section 18 of the Border Guard Law, the second option is to use firearms because "there is no other way of arresting the person..."

In the first case, we do not comply with the requirements of Paragraph 4, Section 13 of the Border Guard Law, which states: “...to not allow persons and means of transport to cross the State border, or freight and other property to be moved across the State border outside the locations provided for this purpose or in any other illegal way, to detect and arrest violators of State borders, as well as detect violators of border area, border area zone, border control point and border crossing point regimens... (Border Guard Law, 1997)"

In the second case, we deliberately shoot at a living person who does not attack us and does not threaten our safety. He just runs away from the border guard. The use of weapons looks somewhat wild from the point of view of a civilised person. So what to do? 
Now let's look at another example. At the border control point, a welldeveloped person, dissatisfied with the actions of the border guards, being unable to cope with the emotions overwhelming him, begins to behave aggressively and resist, ignoring the legal demands of the border guards. He is opposed by a fragile girl who has a special tool, namely, a baton. Who will logically be the winner in this situation? What to do after all?

And yet there is a fairly credible deterrent that allows you to solve such problems effectively and with minimal risk. With that, both the border guard and the violator remain alive. At the same time, the border guard fulfils his duties, and the offender realises that he was wrong. This device is an electroshock weapon of non-lethal action, which allows you to minimise injury and death during the arrest of a violator and able to hit a target at a distance of 4.5 to 10 meters. The electroshock weapon is a means used in cases when it is too early to use a firearm, and too late for other special devices.

The use of an electroshock weapon of non-lethal action is determined by the Cabinet Regulations: "An electroshock weapon shall be used if it is necessary to temporarily paralyse a person or an animal with a high voltage electric discharge. It is prohibited to send the electric discharge to the head, groin or heart area. (Cabinet Regulation No.55, 2011"

Currently, the Latvian Border Guard has such a special tool at its disposal. Almost every division has it, but, unfortunately, not enough. The second problem is the insufficient level of personnel's skills to apply such devices. As a result, electroshock weapons gather dust in warehouses and in arms rooms, but are rarely brought out.

American company Taser® International is a world leader in the development, production and distribution of personal electronic non-lethal weapons. The company was founded in 1993 and its name was Air Taser $®$, which corresponded to its first product - a self-protection device against electric shock. Today, it exports its products to over 60 countries. Many violent conflict situations do not require the use of lethal force or weapons to resolve them, but in such cases it is impossible to fully defend against aggressive actions. Effective non-lethal weapons increase the safety of police officers and detainees, save lives, help avoid lengthy and embarrassing lawsuits and improve public attitudes towards the law enforcement agencies. The Taser is positioned as a non-lethal and almost completely safe for human health device intended for use by the police in cases of chasing a criminal, against resisting arrest or detention, and for use on potentially dangerous people, in relation to whom, in a standard situation, firearms could be used. In a number of countries, the use of the Taser is included in the national principles of the use of force as one of the stages of influence on a suspect (Products, webpage). 
At the moment, in the inventory of the Latvian Border Guard there is the TASER X26 stun gun. As the name of the device suggests, the electric discharge output is $26 \mathrm{~W}$, but the generated pulse wave form is slightly different and produces a stronger effect. The shape of the casing is designed to reduce size and facilitate portability. The only moving parts are the tongue and double-sided safety lever. Length with loaded cassette is $18 \mathrm{~cm}$, height $-8 \mathrm{~cm}$, thickness $-3.3 \mathrm{~cm}$, weight -270 grams. The casing is made of black, yellow or transparent plastic with overlays. Classic sighting devices are used. In addition, $650 \mathrm{~nm}$ laser optics and a diode lamp are installed.

A switch on the front of the viewpoint allows you to select one of four types of target irradiation: laser and flashlight, laser only, flashlight only, laser and flash are off. The liquid crystal display with two digits faces the shooter and informs about the discharge of the battery, calculates the remaining seconds of operation, the results of system diagnostics, the time and temperature of the weapon system. When the safety lever is pressed in the down position, the weapon is ready for use.

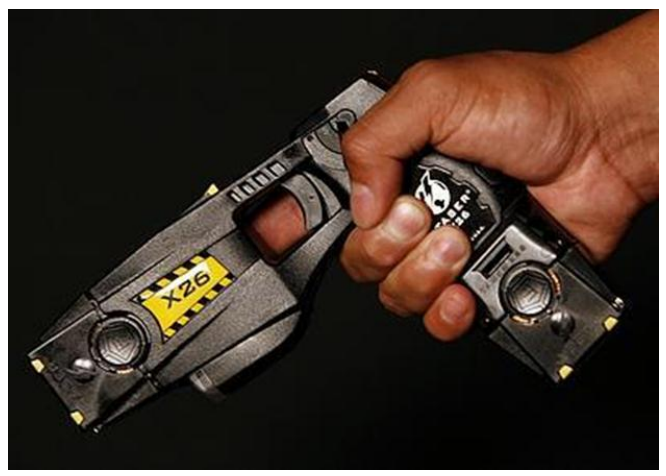

Figure 1. TASER X26 stun gun (Source: Products, webpage)

The X models do not have usage data records. However, instead of a battery pack that can be inserted into the grip, a Taser CAM module has been added, which consists of a battery and a miniature video camera with memory that can record the actions of a person using a stun device for up to 1.5 hours. The record is read by a computer.

The Taser shoots two small electrodes in the form of two barbed needles that transmit electrical discharge through two copper wires that remain attached to the main cartridge assembly. The shot is made using the compressed nitrogen gas propellant cartridge, as in some pneumatic guns and paintball markers. The cartridge contains enough compressed gas to fire one shot. After firing, the cartridge is replaced. A spare cartridge is 
located at the bottom of the grip and, in case of a miss, quickly replaces the shot one.

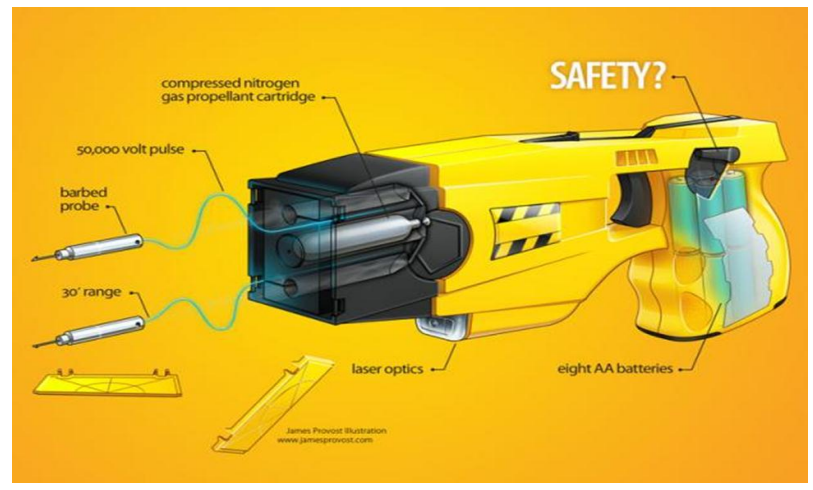

Figure 2. TASER X26 stun gun mechanism (Source: Products, webpage)

The main technology of Tasers is based on the use of an electric discharge that causes neuromuscular paralysis. The electric discharge interrupts the brain's ability to control the muscles in the body, which creates an immediate and complete loss of balance and a temporary loss of the ability to move. This effect is not based on pain and cannot in any way be overcome by a person's volitional effort. As soon as the electric discharge ends its effect, the person immediately regains full control over the body. Most detainees who have experienced electric discharge from Tasers begin to behave more submissively to avoid re-discharge. Two harpoon electrodes pierce even a thick layer of clothing at a distance of up to $7.5 \mathrm{~m}$, while $50,000 \mathrm{~V}$ cause a powerful convulsion throughout the body.

The use of the stun gun has a "de-escalation effect" on violators. Indeed, quite often, to calm the situation, it is enough just to threaten with its application and not to use it. Therefore, when using the stun gun in a real situation, there are several stages of its application. The first stage provides for a visual demonstration of a border guard armed with a stun gun, as well as a simultaneous verbal impact on the violator and warning about the use of the stun gun in case of disobedience. If this is not enough and the situation continues to escalate, then the border guard proceeds to the next steps. He touches the stun gun and demonstrates his readiness to take it out of the holster. Further, in case of disobedience, he continues to apply the following steps of using the stun gun: he takes it out of the holster, turns on the laser sight and aims at the violator, demonstrates an electric arc by 
removing the cartridge. If all these methods of impact do not help "sober up" the violator, then the border guard aims at the violator's chest and fires a shot while saying loudly: "Taser, taser".

The impact on the violator lasts 5 seconds. After 5 seconds, the border guard, having analysed the situation, approaches the violator for several steps and again proposes to fulfil the legal requirements and warns about the repeated use of the stun gun. Usually one time is enough for the violator to stop resisting and go to cooperate with the border guard officer. If the violator continues to resist, then the stun gun application is repeated by simply pulling the trigger.

If, after the shot, the stun gun needles missed the violator or could not pierce the clothes, the second shot is fired. To do this, the cartridge is quickly changed to a spare one (after putting the stun gun on the safety lever) following by pointing and firing. In extreme situations, if it was not possible to quickly recharge the stun gun, it can be used in close combat by impacting on the violator directly with the electric arc.

Despite the positive feedback from many officers of law enforcement agencies, there are also opponents of the use of stun guns. In particular, in 2015, an investigative film by American director Nick Berardini was released in the United States. The film is based on the consideration of cases of the use of Taser stun guns. In an interview, the director expressed the opinion that the danger posed by stun guns is underestimated. Shocking archival footage accompanies candid interviews with cardiologists, lawyers, police officers, politicians, families who lost loved ones after using the Taser stun gun against them, and a representative of Taser International.

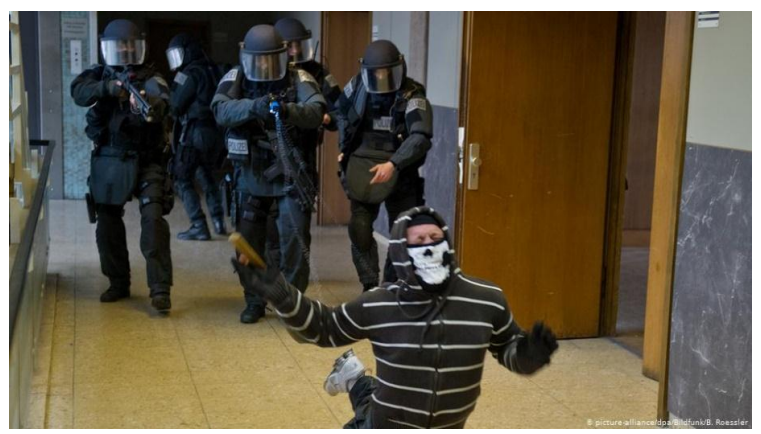

Figure 3. Application of TASER X26 stun gun (Source: Products, webpage)

Similar incidents occur regularly around the world. For example, in Russia, two law enforcement officers from Irkutsk hit a 24-year-old local resident with a stun gun to wake him up - as a result, he died of heart 
failure. According to the mother of the deceased, her son was returning home from a club, was drunk and fell asleep in a taxi. After the driver was unable to wake him up, he turned to the security officers, who are now accused of abuse of office.

A similar case occurred in the town of Pirmasens in South-Eastern Germany. A person with a mental disorder had to be transported from his own apartment to the hospital. As he resisted as best he could, the police officer used a stun gun against him, from which the 56-year-old man never recovered. He lost consciousness in the police car and died shortly after arriving at the hospital.

The prosecutor's office is investigating this incident. So far, a direct causal relationship between the use of the stun gun and the death of a victim has not been established, since it is necessary to take into account a lot of factors that could affect the condition of the man. Meanwhile, the tragic incident in Pirmasens is far from the only one. Three more similar incidents have been reported in Germany. According to a study by Reuters, over the past 20 years in the United States alone, a total of about a thousand people have died as a result of the use of stun guns. Meanwhile, in 153 cases, the results of the examination indicated death from the consequences of an electric shock or shocks without any additional factors affecting the body.

There are certain risk groups when using a stun gun. "In such cases, a healthy person cannot have any serious problems," Thomas Deneke, Head Physician in one of the hospitals in Bavaria specialising in cardiovascular diseases says. However, Deneke adds, if a person has heart problems or is taking certain medications or drugs, a shock by a stun gun can be lifethreatening. This is precisely the major issue. The Taser is a proven device against people who are trying to commit suicide, as well as aggressive people with mental impairment. They often take medication or are under the influence of drugs. Among other things, they are in a state of extreme stress. All this at least contributes to the fact that an electric shock can lead to a heart attack.

\section{Conclusions}

That said, despite such statistics, there are undoubtedly more cases when a stun gun saved the life and health of a law enforcement officer and other people. The number of cases in which firearms are used and people die is many times greater. What then? Should we prohibit officers of power structures and law enforcement agencies to use firearms? Weapons and special devices are not applied against law-abiding citizens. Offenders are also given the choice to comply with legal requirements or to continue the illegal actions before using arms against them. Before using firearms and 
special devices, a law enforcement officer warns the violator about the use of one or the other. Therefore, in most cases, the violator has an informed choice. In the event of a sudden attack, the stun gun remains out of competition. Skilful and quick use of the stun gun in most cases will save the life and health of both the law enforcement officer and the violator.

Taking into account the experience and specificity of the Latvian Border Guard, the use of stun guns (in particular Tasers) would be more effective and justified than the use of firearms and special devices. Correct organisation of the training process for the use of stun guns, psychological training of personnel can significantly increase the level of competence of Latvian Border Guard officers, as well as increase their protection from the actions of violators.

Today practically every division of the Latvian Border Guard has Taser stun guns. However, the problem lies in the fact that there is a shortage of them to fully equip the Latvian Border Guard officers performing service duties related to the immediate protection of the state border and control of the immigration regime. Also, not much attention and time is paid to training the officers of the Latvian Border Guard on the use of stun guns. Each unit has certified professionals, whose main task is to train officers, but still, the officers are not able to answer questions about stun guns with confidence and knowledge of the matter, which indicates an insufficient degree of training in the Latvian Border Guard units.

How can this problem be solved? First, it is necessary to find an opportunity to purchase Taser stun guns in an amount sufficient to provide the personnel of the Latvian Border Guard involved in immediate protection of the state border and control of the immigration regime. Second, to organise high-quality training of personnel on the use of stun guns (training courses for at least three days), using instructors available in each unit, and, if necessary, involving lecturers of the State Border Guard College or foreign experts. Third, to ensure regular training in the use of stun guns for the personnel of the Latvian Border Guard units involved in the immediate protection of the state border and control of the immigration regime. And finally, fourth, to bring out stun guns to officers along with other special devices for the duration of their service duties related to the immediate protection of the state border and control of the immigration regime.

According to the authors, the fulfilment of the above conditions will allow not only to increase the effectivity of performing tasks and duties by the Latvian Border Guard officers but also significantly increase the prestige of the Latvian Border Guard. 


\section{References}

1. 1997.gada 27.novembra likums "Robežsardzes likums" - Latvijas Vēstnesis 1997. - 329/330. Retrieved August 7, 2020, from: https://likumi.lv/ta/id/46228-robezsardzes-likums;

2. 1998.gada 17.jūnija likums "Krimināllikums" - Latvijas Vēstnesis - 1998. Nr.199/200. Retrieved August 7, 2020, from: https://likumi.lv/ta/id/88966-kriminallikums;

3. Ministru kabineta 2011.gada 18.janvāra noteikumi Nr.55 "Noteikumi par speciālo līdzekḷu veidiem un to lietošanas kārtību" - Latvijas Vēstnesis - 2011. - 15. Retrieved August 7, 2020, from: https://likumi.lv/ta/id/224905-noteikumi-par-specialo-lidzeklu-veidiem-un-to-l ietosanas-kartibu

4. Products webpage - Retrieved August 7, 2020, from: www.axon.com. 